\title{
Threatened flora from the State of Santa Catarina, Brazil: Arecaceae ${ }^{1}$
}

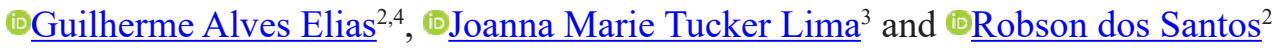

Received: 21 March 2018; accepted: 21 November 2018

How to cite: Elias, G.A., Lima, J.M.T. \& Santos, R. 2019. Threatened flora from the State of Santa Catarina, Brazil: Areaceae. Hoehnea 46: e052018. http://dx.doi.org/10.1590/2236-8906-05/2018.

\begin{abstract}
Threatened flora from the State of Santa Catarina, Brazil: Arecaceae) Palms (Arecaceae) are key elements that contribute to the forest biodiversity of the State of Santa Catarina. However, the official List of Endangered Flora Species of that State is incomplete, including only two Arecaceae species (Butia catarinensis Noblick \& Lorenzi and B. eriospatha (Mart. Ex Drude) Becc.). Within this context, this study proposes a revision of the Official List of Arecaceae for Santa Catarina, based on the assessment of the conservation status made for each of the State's native palm species. To assess the conservation status of the palm species in Santa Catarina, important sources on species distribution were used, including the Global Biodiversity Information Facility (GBIF), a compilation of previously published, herbarium information, field observations, and data from the Floristic and Forest Inventory of Santa Catarina (IFFSC). Information for each species was imported into GeoCAT software (Geospatial Conservation Assessment Tool). All 11 native palm species of Santa Catarina were evaluated. Ten species were considered at risk of extinction according to the IUCN Red List categories and criteria. This large number of palm species at risk of extinction calls attention to the urgent need for updates of the Official List of Endangered Species in the State.

Keywords: Atlantic Forest, biodiversity, Floristic and Forest Inventory of Santa Catarina State, International Union for Conservation of Nature, Palmae
\end{abstract}

RESUMO - (Flora Ameaçada do Estado de Santa Catarina, Brasil: Arecaceae). As palmeiras (Arecaceae) são elementos-chave que contribuem para a biodiversidade florestal do Estado de Santa Catarina. No entanto, a Lista Oficial de Espécies da Flora Ameaçadas para o Estado de Santa Catarina é incompleta, incluindo apenas duas espécies desta família (Butia catarinensis Noblick \& Lorenzi e B. eriospatha (Mart. Ex Drude) Becc.). Neste contexto, o presente estudo propõe uma revisão desta lista para a família Arecaceae, com base nas avaliações do status de conservação realizadas para cada um dos táxons nativos do Estado. Para isso foram utilizadas importantes fontes de dados sobre a distribuição das espécies, incluindo o Global Biodiversity Information Facility (GBIF), uma compilação de pesquisas publicadas, dados de coleta dos herbários do Estado, observações e dados do Inventário Florístico Florestal de Santa Catarina (IFFSC). As informações para cada espécie foram importadas para o software GeoCAT (Geospatial Conservation Assessment Tool). Foram avaliadas todas as 11 espécies de palmeiras nativas. Dez espécies foram consideradas em risco de extinção, pelas categorias e critérios da Lista Vermelha da IUCN. O grande número de espécies de palmeiras em risco de extinção chama atenção para a necessidade urgente de atualizações da lista oficial de espécies ameaçadas do Estado.

Palavras-chave: Biodiversidade, Floresta Atlântica, Inventário Florístico Florestal de Santa Catarina, Palmae, União Internacional para Conservação da Natureza

\section{Introduction}

The Brazilian State of Santa Catarina plays a critical role in the conservation of regional biodiversity (Azevedo-Santos et al. 2017), as it is the only State once completely covered by the Atlantic Forest, one of the most fragmented and threatened Brazilian biomes (Lucas \& Bunger 2015). The current status of Santa
Catarina forests highlights calls for action, since the State maintains only $29 \%$ of its remaining forest cover, mostly comprised of secondary forests, which have suffered drastic reductions in diversity over the last 50 years (Reitz et al. 1979, Vibrans et al. 2013a).

Palms (Arecaceae) are key elements contributing to Santa Catarina's forest biodiversity, due to their wide geographic distribution and ecological and traditional

1. Parte da Tese de Doutorado do primeiro Autor

2. Universidade do Extremo Sul Catarinense, Herbarium Pe. Dr. Raulino Reitz (CRI), Av. Universitária, 1105, Bairro Universitário, 88806-000 Criciúma, SC, Brasil

3. Montgomery Botanical Center, Old Cutler Rd, 33156-4242 Coral Gables, Flórida, Estados Unidos

4. Corresponding author: guilherme@unesc.net 
importance (Dransfield et al. 2008); however, few published scientific papers cover palm species native to Santa Catarina, and some species are completely absent from the scientific literature (Elias et al. 2015). The paucity of research on native Santa Catarina palms and a lack of public conservation policies put these species at imminent risk of extinction within the State.

The official List of Endangered Flora Species for the State of Santa Catarina (Consema 2014) includes only two Arecaceae species (Butia catarinensis Noblick \& Lorenzi and B. eriospatha (Mart. ex Drude) Becc.), among the 11 species native to the State (Elias et al. 2016). In contrast, the official List of Endangered Flora Species for the neighboring State of Rio Grande do Sul (Rio Grande do Sul, Brazil, 2014) provides a complete evaluation of that State's 15 native palm species and classifies 13 of these as 'at risk of extinction' (Soares et al. 2014). To classify its flora, Rio Grande do Sul followed established IUCN Red List criteria; Santa Catarina did not.

Within this context, due to the importance of palms in Santa Catarina forests and the lack of associated information and inclusion criteria, this study proposes a revision to the Official List of Endangered Flora Species for the State of Santa Catarina for the family Arecaceae, based on conservation status assessments carried out for each of the State's native palm species.

\section{Materials and methods}

The State of Santa Catarina is located in southern Brazil, where the climate, according to the Köppen system, is humid subtropical with no strictly defined dry season, and hot $(\mathrm{Cfa})$ or balmy summers $(\mathrm{Cfb})$, corresponding to $40 \%$ and $60 \%$ of the study area,

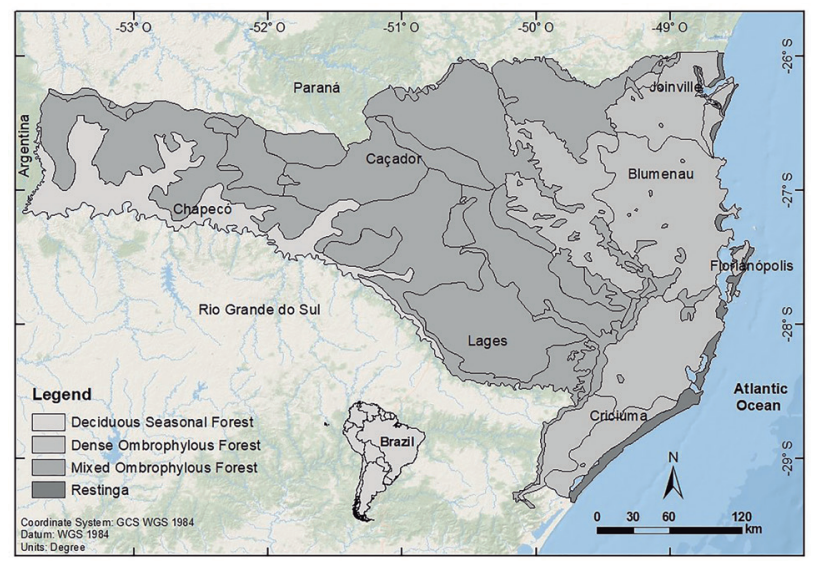

Figure 1. Vegetation formations in the State of Santa Catarina. Adapted from the Klein's map (Klein 1978). respectively (Alvares et al. 2013). Rainfall is well distributed, averaging 1250-2000 $\mathrm{mm} \mathrm{yr}^{-1}$, and no part of the State experiences regular droughts (Nimer 1990). The predominant vegetation types in Santa Catarina include Deciduous Seasonal Forest, Dense Ombrophylous Forest, Mixed Ombrophylous Forest and Restinga (Pioneering Formations of Marine and Fluvial Influence) (IBGE 2012, figure 1).

To assess the conservation status of palm species in Santa Catarina, key data sources on species distributions were used, including the Global Biodiversity Information Facility (GBIF), a compilation of published research on palm distributions in Santa Catarina, collections data from Santa Catarina herbariums (CRI, FLOR, HBR, FURB, JOI and LUSC), field observations by the authors and data from the Floristic and Forest Inventory of Santa Catarina (IFFSC). Information for each species was imported into GeoCAT (Geospatial Conservation Assessment Tool), an open-source web software that integrates primary biological data for semi-automated IUCN Red List assessment and analysis (figure 2). We used this tool to perform rapid geospatial analysis and assess the conservation status of Santa Catarina palm species based on the threat of extinction. Applying spatially referenced primary occurrence data, GeoCAT focuses on two aspects of a taxon's geographic distribution: the extent of occurrence (EOO) and the area of occupation (AOO). These metrics are part of the IUCN Red List categories and criteria (see Bachman et al. (2011) for more detail).

We also considered recently published works on forest remnants and palms in Santa Catarina, (Vibrans et al. 2012a, b, Vibrans et al. 2013a, b, c, Elias et al. 2015, Elias et al. 2016, Elias et al. 2018)

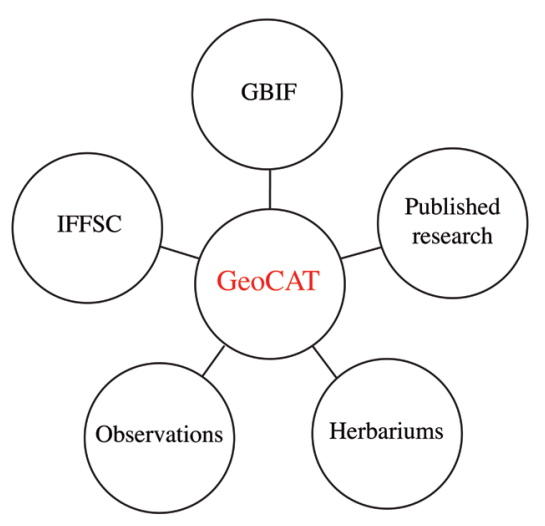

Figure 2. Schematic summary of the data and tools used for conservation status assessments. 
that highlight other important aspects of conservation status besides EOO and AOO, such as the number of occurrence localities, subpopulations and degree of fragmentation.

\section{Results and Discussion}

We evaluated all 11 palm species native to Santa Catarina (Reitz 1974, Elias et al. 2015, Elias et al. 2016, Elias et al. 2018) listed in table 1.

Critically Endangered - Astrocaryum aculeatissimum was the only species classified as Critically Endangered (CR), the most threatened category before being considered Regionally Extinct (RE). The only known collection point for this species is a single location in the municipality of Garuva, extreme northeast of Santa Catarina (Reitz 1974). According to the criteria, this species presents a restricted geographic distribution with an extent of less than $100 \mathrm{~km}^{2}$, as well as a continuous decline in the area of occupation and quality of its habitat (B1b (i, ii, iii)).

In 1998, the national evaluation of CNCFlora (2017) classified Astrocaryum aculeatissimum as a species of Least Concern (LC), mainly due to its wide distribution across the Atlantic Forest, stretching from the State of Santa Catarina to State of Espírito Santo (Flora do Brasil 2020 under construction 2017). Nonetheless, within Santa Catarina, A. aculeatissimum is in danger of local extinction, since its small population is threatened by irreversible disturbance, as has already occurred in the State of São Paulo, where the natural landscapes occupied by this species were converted into streets and other infrastructure projects
(Guedes et al. 2006), leading to the disappearance of seed dispersers (Donatti 2004).

Endangered - Five palm species were classified as Endangered (EN), including Attalea dubia, Butia catarinensis, B. eriospatha, Geonoma elegans, and Trithrinax acanthocoma; however, each species exhibited different criteria. Attalea dubia demonstrated population decline, either observed or suspected to have occurred in the past, and the factors driving this decline show no signs of stopping (A2ac). Although this species has yet to be evaluated in Brazil as a whole, in Santa Catarina it deserves special attention, especially because of its low densities and discontinuous and irregular distribution (Reitz 1974, Elias et al. 2016).

Attalea dubia occurs naturally in forested environments of northern Santa Catarina and northward to the State of Espírito Santo (Flora do Brasil 2020 under construction 2017). In Santa Catarina, it is generally observed on rock formations and in cultivated areas where individuals were spared from felling and fire (Reitz 1974). This fragmented distribution, associated with the disappearance of seed dispersers, has all but halted regeneration in these populations, seriously threatening the continuity of A. dubia in the State (Elias et al. 2016).

Butia catarinensis also finds itself in a precarious situation due to its restricted geographic distribution within an area of occupation less than $2000 \mathrm{~km}^{2}$. This species presents severe fragmentation and continuous deterioration of the area of occupation, extent of occurrence and habitat quality (B2ab (i, ii,

Table 1. Conservation status and criteria for the Santa Catarina native palm species based on the IUCN guidelines (2016): Critically Endangered (CR); Endangered (EN) Vulnerable (VU); Least Concern (LC). Voucher: catalog number from CRI (Pe. Dr. Raulino Reitz Herbarium) and HBR (Barbosa Rodrigues Herbarium).

\begin{tabular}{|c|c|c|c|c|}
\hline Scientific name & Author & Voucher & Status & Criteria \\
\hline Astrocaryum aculeatissimum & (Schott) Burret & HBR 5815 & $\mathrm{CR}$ & B1b(i, ii, iii) \\
\hline Attalea dubia & (Mart.) Burret & CRI 11567 & EN & A2ac \\
\hline Bactris setosa & Mart. & CRI 11458 & VU & $\mathrm{A} 2 \mathrm{abc}$ \\
\hline Butia catarinensis & Noblick \& Lorenzi & CRI 10996 & EN & B2ab(i, ii, iii) \\
\hline Butia eriospatha & $\begin{array}{c}\text { (Mart. ex Drude) } \\
\text { Becc. }\end{array}$ & CRI 10995 & $\mathrm{EN}$ & A4acd \\
\hline Euterpe edulis & Mart. & CRI 11565 & VU & A4acd \\
\hline Geonoma elegans & Mart. & CRI 11562 & EN & B1ab(i, ii, iii) \\
\hline Geonoma gamiova & Barb.Rodr. & CRI 10979 & VU & $\mathrm{A} 2 \mathrm{abc}$ \\
\hline Geonoma schottiana & Mart. & CRI 11790 & VU & $\mathrm{A} 2 \mathrm{abc}$ \\
\hline Syagrus romanzoffiana & (Cham.) Glassman & CRI 10980 & $\mathrm{LC}$ & Nenhum \\
\hline Trithrinax acanthocoma & Drude & HBR 36170 & EN & B2ab(i, ii, iii) \\
\hline
\end{tabular}


iii)). Butia catarinensis has yet to be evaluated for the threat of extinction in Brazil, even though the Restinga - the native vegetation where this species occurs - has been under constant urban pressure and is highly fragmented (Vibrans et al. 2013c). While $B$. catarinensis occurs extensively between Rio Grande do Sul and Santa Catarina (Flora do Brasil 2020 under construction 2017) its populations are irregular distributed (Elias et al. 2016), facing constant pressure from logging and extraction for ornamental plantings, as well as land speculation (Reitz 1974, Santos et al. 2017).

Butia eriospatha also suffers from extraction pressures, mainly for ornamental use, in which individuals are removed from their natural habitat and planted for display in parks (Elias et al. 2016). This species suffers population decline, both observed and projected, with the causes of decline unchecked (A4acd). Although B. eriospatha is classified nationally and internationally as VU, in Santa Catarina we recommend it be classified as EN, since it presents a decline in area of occupation and elevated levels of exploitation.

Butia eriospatha occurs from Rio Grande do Sul to Paraná (Flora do Brasil 2020 under construction 2017), and grows exclusively in Natural Fields (steppes in high elevation regions), an environment that has experienced a $25 \%$ reduction in total area over the last 30 years, mainly due to agricultural expansion (Overbeck et al. 2009, Hoffmann et al. 2014). Loss of habitat, the illegal sale of specimens, exploitation of its fruits and the infiltration of cattle into their areas of occurrence have compromised the conservation of B. eriospatha (Barbieri et al. 2014, Elias et al. 2016).

Like Astrocaryum aculeatissimum, the extent of occurrence for Geonoma elegans is extensive, occurring from the State of Santa Catarina to the State of Bahia (Flora do Brasil 2020 under construction in 2017). Within Santa Catarina, however, this species covers only a small area $\left(<5,000 \mathrm{~km}^{2}\right)$, presenting severe fragmentation and a continuous decline in the area of occupation, extent of occurrence and habitat quality (B1 ab (i, ii, iii)).

Geonoma elegans only grows in the northern part of Santa Catarina within a federally declared biodiversity conservation area, which was assigned very high priority by the Brazilian government (Elias et al. 2018). Geonoma elegans exhibits narrow habitat requirements, mainly associated with unique edaphic condition (Reitz 1974). Its limited range, coupled with specific environmental needs, makes G. elegans highly susceptible to disturbance. This species could easily disappear from Santa Catarina forests if human activity and economic development continue to advance into the area, or conservation measures are ignored (Elias et al. 2018).

Another species with specific habitat requirements is Trithrinax acanthocoma, growing exclusively along the southern plateau of Brazil in the States of Paraná, Santa Catarina and Rio Grande do Sul (Flora do Brasil 2020 under construction 2017). In Santa Catarina, this species exhibits a restricted geographic distribution (area of occupation $<2,000 \mathrm{~km}^{2}$ ) and suffers from severe fragmentation with a continuous decline in the area of occupation, extent of occurrence and habitat quality (B2ab (i, ii, iii)).

Trithrinax acanthocoma is characteristic of Mixed Ombrophylous Forest and is associated with smaller, more fragmented forest remnants in Santa Catarina (Vibrans et al. 2013b). It is commonly observed in open fields or found along the edges of Araucaria forests (Reitz 1974). Besides its low natural abundance (Reitz 1974), T. acanthocoma has experienced habitat degradation in recent years and risks disappearing from the State if such transformations to the landscape continue.

Vulnerable - Four species were classified as Vulnerable (VU): Bactris setosa, Euterpe edulis, Geonoma gamiova, and G. schottiana. All enjoy large areas of occupation and extent of occurrence within Santa Catarina in low altitudes; however, they are species that depend on a closed forest environment (Elias et al. 2016, Elias et al. 2018). All four species present observed and predicted population decline (i.e., past, present and future) with persistent causes of decline (A4abc).

The vulnerability of these palm species is related to establishment requirements and community continuity, since they rely on conditions found in the forest interior, such as shade, humidity and slope (Reitz 1974). Therefore, the maintenance of these species is closely linked to the environment, being directly proportional to habitat quantity and quality (Elias et al. 2018).

For Euterpe edulis, criteria are different, since it presents a decline in observed and projected populations (i.e., past, present and future), as well as continuous causes of decline and an obvious decline in habitat quality with detrimental levels of exploitation (A4acd). In spite of an extensive area of occupation and occurrence throughout the Dense Ombrophylous 
Forest (Elias et al. 2016), E. edulis has suffered from historically high levels of predatory exploitation for heart of palm, compromising entire populations (Reitz 1974, Reis et al. 2000).

In the national assessment, Euterpe edulis is also classified as VU, mainly due to the following factors: non-cespitose growth form, slow growth, and dependence on well-preserved forests (CNCFlora 2017). In Santa Catarina, the degradation of forests associated with indiscriminate exploitation is still moving forward, jeopardizing the continuity and survival of this species (Vibrans et al. 2013c).

Least Concern - Syagrus romanzoffiana was the only species considered as Least Concern (LC), both for Santa Catarina and for Brazil as a whole (CNCFlora 2017). This species is widely distributed, with extensive occurrence and area of occupation. In the State of Santa Catarina, it occurs in all vegetation types and displays the highest dominance among all the State's palm species (Elias et al. 2016). In addition, S. romanzoffiana presents high ecological plasticity, high levels of natural regeneration and is widely used in ornamental plantings along streets and parks (Lorenzi 2004, Zimmermann et al. 2011).

The large number of palm species at risk of extinction in Santa Catarina, associated with the fragmented and threatened status of the remaining forest in the State, calls attention to an urgent need for updates to the State's official list of endangered species. In addition, data inconsistencies within the official List of Species of the Endangered Flora for the State of Santa Catarina resulted in the occasional use of ancillary lists, such as those published for the World, for Brazil or for neighboring States, such as Paraná and Rio Grande do Sul. These secondary data can distort information on the effective conservation status of a given species. Therefore, we consider it essential that the official list of palms in Santa Catarina be updated and strongly recommend that updates be extended to the other botanical families of native occurrence in Santa Catarina as well.

\section{Acknowledgements}

The present authors would like to express their thanks to Floristic and Forest Inventory of Santa Catarina team for collecting and sharing the data used in this paper and the financial support from the Foundation for Research and Innovation Support of the State of Santa Catarina and from Coordination for the Improvement of Higher Education Personnel (CAPES) for the first author's scholarship funding.

\section{Literature cited}

Alvares, C.A., Stape, J.L., Sentelhas, P., Gonçalves, J.L.M. \& Sparovek, G. 2013. Köppen's climate classification map for Brazil. Meteorologische Zeitschrift 22: 711-728.

Azevedo-Santos, V.M., Fearnside, P.M., Oliveira, C.S., Padial, A.A., Pelicice, P.M., Lima Júnior, D.P., Simberloff, D., Lovejoy, T.E., Magalhães, A.L.B., Orsi, M.L., Agostinho, A.A., Esteves, F.A., Pompeu, P.S., Laurance, W.F., Ptrere Junior, M., Mormul R.P. \& Vitule J.R.S. 2017. Removing the abyss between conservation science and policy decisions in Brazil. Biodiversity and Conservation 26: 1-8.

Bachman, S., Moat, J., Hill, A.W., de La Torre, J., Scott, B. 2011. Supporting Red List threat assessments with GeoCAT: geospatial conservation assessment tool. ZooKeys 150: 117-126.

Barbieiri, R., Gomes, J., Alercia, A., Padulosi, S. 2014. Agricultural biodiversity in southern Brazil: integrating efforts for conservation and use of neglected and underutilized species. Sustainability 6:741-757.

CNCFlora. 2017. Astrocaryum aculeatissimum. Available at http://cncflora.jbrj.gov.br/portal/pt-br/profile/ Astrocaryum aculeatissimum (access in 27-IV-2017).

CNCFlora. 2017. Euterpe edulis. Available at http:// cncflora.jbrj.gov.br/portal/pt-br/profile/Euterpe edulis (access in 28-IV-2017).

CNCFlora. 2017. Syagrus romanzoffiana. Available at http://cncflora.jbrj.gov.br/portal/pt-br/profile/Syagrus romanzoffiana (access in 28-IV-2017).

CONSEMA - Conselho Estadual do Meio Ambiente. 2014. Resolução n. 51/2014. Lista oficial das espécies da flora ameaçada de extinção no estado de Santa Catarina. Available at https://goo.gl/uADUcv (access in 9-V-2017).

Donatti, C.I., Guimarães Junior, P.R. \& Galetti, M. 2009. Seed dispersal and predation in the endemic Atlantic Rainforest palm Astrocaryum aculeatissimum across a gradient of seed disperser abundance. Ecological Research 24: 1187-1195.

Dransfield, J., Uhl, N.W., Asmussen, C.B., Baker, W.J., Harley, M.M. \& Lewis, C.E. 2008. Genera Palmarum: The Evolution and Classification of Palms. London, Royal Botanic Kew.

Elias, G.A., Corrêa, P.F., Citadini-Zanette, V. \& Santos, R. 2015. Arecaceae: Análise bibliométrica das espécies nativas do estado de Santa Catarina. Ciência e Natura 37: 85-92.

Elias, G.A., Gasper, A.L., Lima, J.M.T., Soares, K.P., Molz, M. \& Santos, R. 2016. Community Structure of Large Native Arborescent Palms (Arecaceae) using data from the Floristic and Forest Inventory of Santa Catarina, Brazil. Australian Journal of Basic and Applied Sciences 10: 156-163. 
Elias, G.A., Gasper, A.L., Lima, J.M.T., Lodetti, G., Santos, R. 2018. Native understory palms (Arecaceae) of the Atlantic Forest in Santa Catarina, Southern Brazil. Rodriguésia 69: 693-698.

Flora do Brasil 2020 (em construção). 2017. Arecaceae. Available at http://floradobrasil.jbrj.gov.br/reflora/ floradobrasil/FB33989 (access in 27-IV-2017).

Guedes, D., Barbosa, L.M. \& Martins, S.E. 2006. Composição Florística e Estrutura Fitossociológica de Dois Fragmentos de Floresta de Restinga no Município de Bertioga, SP, Brasil. Acta Botanica Brasilica 20: 299-311.

Hoffman, J.F., Barbieri, R.L., Rombaldi, C.V., Chaves, F. C. 2014. Butia spp. (Arecaceae): An overview. Scientia Horticulturae 179: 122-131.

IBGE. 2012. Manual Técnico da Vegetação Brasileira. Rio de Janeiro, IBGE.

IUCN. 2016. Guidelines for using the IUCN red list categories and criteria. Version 12. Available at http:// www.iucnredlist.org/documents/RedListGuidelines.pdf (access in 9-V-2017).

Klein, R.M. 1978. Mapa fitogeográfico do estado de Santa Catarina. Itajaí, SUDESUL, FATMA, Herbário Barbosa Rodrigues.

Lucas, E.J. \& Bünger, M.O. 2015. Myrtaceae in the Atlantic forest: their role as a 'model' group. Biodiversity and Conservation. 24: 2165-2180.

Lorenzi, H., Noblick, L., Kahn, F. \& Ferreira, E. 2010. Flora Brasileira: Arecaceae (Palmeiras). Nova Odessa, Instituto Plantarum.

Nimer, E. 1989. Climatologia do Brasil. Rio de Janeiro, IBGE, Departamento de Recursos Naturais e Estudos Ambientais.

Overbeck, G.E., Müller, S.C., Fidelis A., Pfadenhauer, J., Pillar, V.P., Blanco, C.C.; Boldrini, I.I., Both, R. \& Forneck, E.D. 2009. Os Campos Sulinos: um bioma negligenciado. In: V.P. Pillar, S.C. Müller, Z.M.S Castilhos, A.V.A Jacques (eds.). Campos Sulinos: conservação e uso sustentável da biodiversidade. Ministério do Meio Ambiente, Brasília, pp. 24-41.
Reis, M.S., Fantini, A.C., Nodari, R.O., Reis, A., Guerra, M.P. \& Mantovani, A. 2000. Management and conservation of natural populations in Atlantic Rainforest: the case study of palm heart (Euterpe edulis Martius). Biotropica 32: 894-902.

Reitz R. 1974. Palmeiras In: R. Reitz (ed.). Flora Ilustrada Catarinense. Itajaí, Herbário Barbosa Rodrigues.

Reitz, R., Klein, M. \& Reis, A. 1979. Projeto Madeira Santa Catarina. Florianópolis, Lunardelli.

Rio Grande do Sul. 2014. Decreto N 52.109 de 10 de dezembro de 2014. Declara as espécies da flora nativa ameaçadas de extinção no Estado do Rio Grande do Sul. Available at http://www.fzb.rs.gov.br/ upload/20141222103647doe.pdf (access in 09-V-2017).

Santos, R., Elias, G.A., Guislon, A.V. \& Zanoni, I.Z. 2017. Vegetação arbustivo-arbórea em uma restinga de Jaguaruna, litoral sul do Estado de Santa Catarina, Brasil. Revista Ambiente e Água 12: 99-111.

Soares, K.P., Longhi, S.J., Witeck Neto, L. \& Assis, L.C. 2014. Palms (Arecaceae) from Rio Grande do Sul, Brazil. Rodriguésia 65: 113-139.

Vibrans, A.C., Sevegnani, L., Gasper, A.L. \& Lingner, D.V. 2012a. Inventário Florestal florístico de Santa Catarina: Floresta Estacional Decidual. Blumenau, Edifurb.

Vibrans, A.C., Sevegnani, L., Gasper, A.L. \& Lingner, D.V. 2012b. Inventário Florístico Florestal de Santa Catarina: Diversidade e Conservação dos Remanescentes Florestais. Edifurb, Blumenau.

Vibrans, A.C., Sevegnani, L., Gasper, A.L., Müller, J.J.V., Reis, M.S. 2013a. Inventário Florístico Florestal de Santa Catarina: Resultados Resumidos. Edifurb, Blumenau.

Vibrans, A.C., Sevegnani, L., Gasper, A.L. \& Lingner, D.V. 2013b. Inventário Florístico Florestal de Santa Catarina: Floresta Ombrófila Mista. Edifurb, Blumenau.

Vibrans, A.C., Sevegnani, L., Gasper, A.L. \& Lingner, D.V. 2013c. Inventário Florístico Florestal de Santa Catarina: Floresta Ombrófila Densa. Edifurb, Blumenau.

Zimmermann, T.G., Begnini, R.M. \& Silva, F.R. 2011. Syagrus romanzoffiana (Jerivá). In: L. Coradin, A. Siminski, A. Reis (eds.). Espécies nativas da flora brasileira de valor econômico atual ou potencial: plantas para o futuro - Região Sul. Brasília, MMA. pp. 812-819. 